\title{
Remittance Inflows, Real Exchange Rate Movements and Sectoral Performance in Nigeria
}

\author{
Afolabi O. Adejumo \\ Department of Development Finance, University of Stellenbosch Business School, South Africa
}

Professor Sylvanus I. Ikhide

\begin{abstract}
The impact of remittance on international trade is often comparable to tariff changes-since exchange rate represents price of tradable goods. The appreciation of real exchange rate brings about increase in relative demand for competing importing tradable goods above domestic tradable goods given demand for non-tradable, since foreign goods are now cheaper in terms of domestic currency and there is high purchasing ability to do so. Resources re-allocation between tradable and non-tradable sector has been significant in Nigeria. Contribution of the agricultural sector to Nigeria's GDP has shrunk over the years with the attendant threat to food production and loss of employment opportunities. This study investigates the linear relationship between remittances and real effective exchange rate on one hand and the impact of remittances and exchange rate on tradable and non-tradable sector in Nigeria. Employing DOLS regression technique on annual data ranging from 1981 and 2013, The study found that remittances influence performance of tradable agriculture, manufacturing sector and merchandise export sector in line with Dutch disease idea. Also, we found evidence that changes in exchange rate act as a channel of impact of Dutch disease on all sectors.
\end{abstract}

Keywords: Dutch disease, Remittances, Exchange rate,

JEL Classification: F40, F41, 010

\section{Introduction}

Remittance inflows and movements in exchange rate across countries is of interest to policy makers, scholars and researchers. The impact of remittance on international trade is often comparable to tariff changes-since exchange rate represents price of tradable goods. Hence both remittances and exchange resources re-allocation effects between tradable and non-tradable sector. Exchange rate movements are a common phenomenon to both developing and developed countries, especially those operating floating exchange rate (to a large extent) and to those operating managed floating exchange rate (to some extent).

However, while developed countries may not exhibit trend appreciation of exchange rate, the same could not be established of developing countries. This argument is particularly relevant in the case of inflows such as remittances to most developing countries. For instance, increase in remittance inflows increases the supply of dollars in the foreign exchange market leading directly to appreciation of exchange rate and increase in income of the recipient countries. The appreciation of real exchange rate in turn brings about increase in relative demand for competing importing tradable goods above domestic tradable goods given demand for non-tradable, since foreign goods are now cheaper in terms of domestic currency and there is high purchasing ability to do so.

Furthermore, assuming that dollar supply in the foreign exchange market is not for its sake but to purchase domestic goods and services. Also, assuming households consume a basket of commodities covering both tradable and non-tradable goods, it is expected that increase in aggregate demand will increase the price (wage and marginal productivity) of nontradable goods relative to import competing tradable sector and since there is a limit to which price of tradable sector can rise because its price is determined internationally. This implies shrinking of tradable goods sector because resources will mobilize to the sector paying higher returns. This is a supply channel.

Also, increased remittance implies appreciation of exchange rate. This generates a spending effect. In other words, foreign goods are cheaper in terms of domestic currency and domestic goods are expensive in terms of foreign currency leading 
to increase in demand for imported tradable goods. The imported tradable goods therefore compete with infant domestic tradable goods sector leading reduction in the tradable sector. This is the demand channel.

The case of Nigeria presents an interesting case study. There have been significant increase (though with some inconsistencies) in remittances in Nigeria, especially between 1993 and 2012 (Figure 1). The real effective exchange rate has experienced a combination of appreciation and depreciation. In terms of sectoral performance, the performance of tradable manufacturing sector is far less that the performance of less tradable services sector in terms of their contribution to gross output. Also, measuring performance in terms of sectoral growth rate, there have been inconsistencies. The question that comes to mind is whether there is enough evidence to conclude that Nigeria has symptoms of Dutch disease or not.

Following from the above, this study seeks to answer the following questions: What is the impact of exchange rates and remittances on tradable and non-tradable sectors in Nigeria? Hence, the objective of this paper is to investigate the evidence for Dutch disease in Nigeria.

This paper is organized into five sections. Section two presents the stylized facts about remittances, real effective exchange rate and performance of tradable (manufacturing) and non-tradable sector (services) sectors in Nigeria. Section three presents the literature review, analytical framework and methodology, while section four deals with the empirical results. Section five concludes the study.

Figure 1: Trend in remittance as a percentage of GDP, REER and Merchandise export as a percentage of GDP in Nigeria.

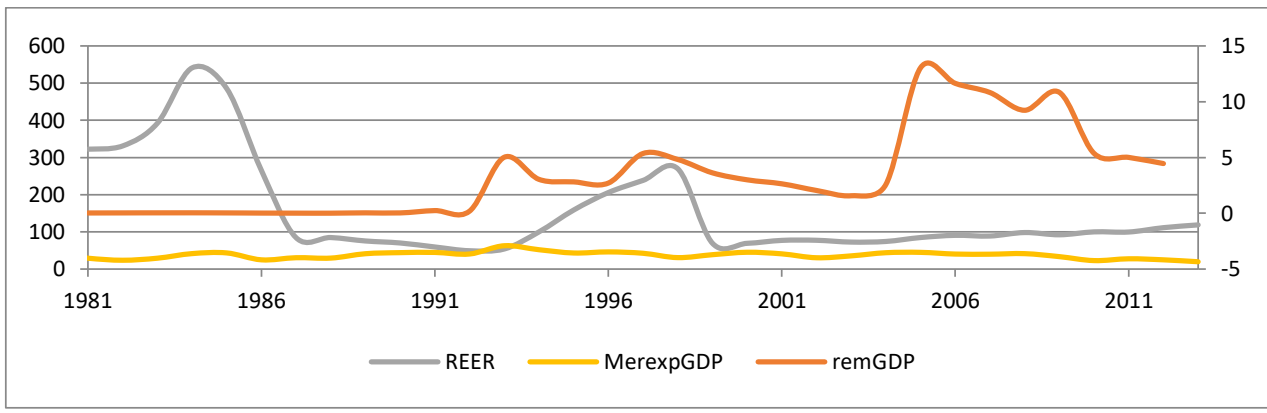

Source: Author's computation based on World Bank (2014)

Note: REER is in the primary y-axis.

\section{Remittances, Real Exchange Effective Rate and Sectoral Performance in Nigeria: Stylized Facts}

Figure 2 shows the trends of personal remittance inflows, exchange rate and sectoral performance in terms of their contribution to GDP in Nigeria. Given the discussion of Dutch disease, it is realised that real effective exchange rate (REER) has been characterised with appreciation and depreciation, and remittances have also experienced considerable upswings and downswings.

The contribution of agricultural and services sector in Nigeria is huge with agriculture sector contributing about 27. 15\% between 1981 and 2013, while services sector contributed about 22. 69\% to GDP within the same periods (Figure 2). However, services sector is catching up with agricultural sector and this became noticeable in the year 2013. The best performing time for the agricultural sector was in 2002. Improved performance of services sector was also noticed at this time. While the agriculture and services sectors have improved over time, the performance of the manufacturing sector has been poor. If we examine the trends of real effective exchange rate (REER) and remittance, little connection could be established. This is because some of the periods of appreciation and deprecation of REER were not really associated with periods of decline in tradable sectors (agricultural and manufacturing sector) and improvement in services sector, respectively. However, services sector has been increasing which is line with the expectation in the discussion of Dutch disease. 
Also, the relationship in the trend movement of remittances as a percentage of GDP and REER seems not to be in line with expectation of Dutch disease.

\section{Figure 2: Remittance, exchange rate and sectoral performance in Nigeria}

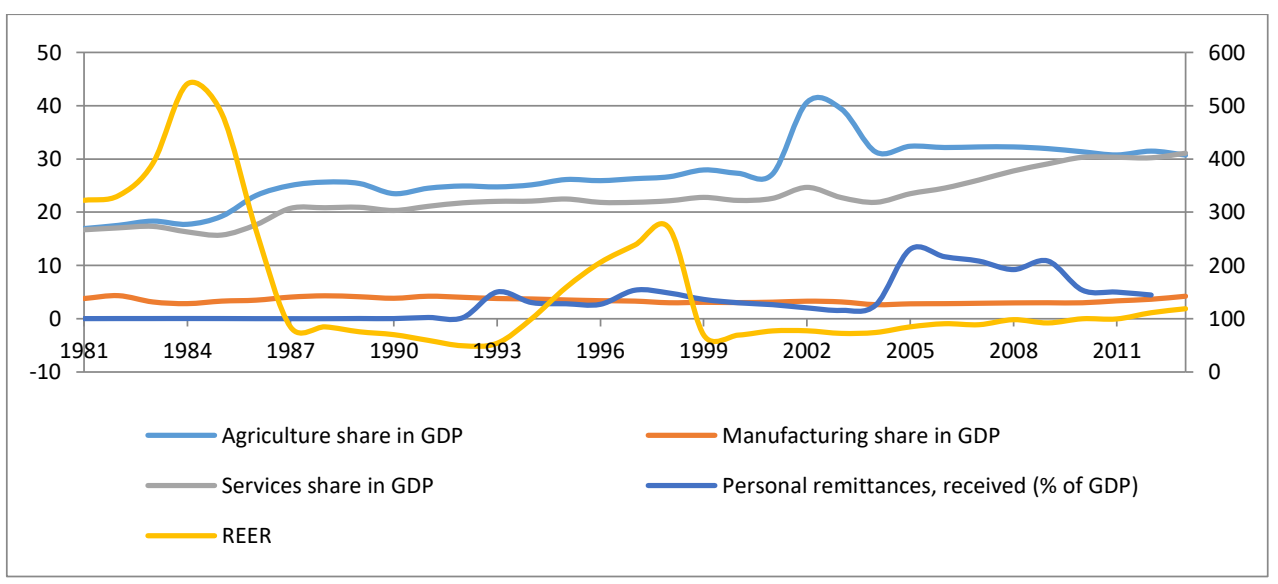

Source: World Bank's World Development Indicators (2014)

Note: REER is in secondary $y$-axis.

\section{Literature Review}

Remittance inflows in many developing countries must have impacted positively on absolute poverty reduction, improve human capital indicators, and reduce inequality (Fajnzylber and López, 2008). However, their magnitude has raised a fundamental question about their undesirable effects on the recipient economies. This undesirable impact is referred to as Dutch disease, depicting the problems that emerged during periods of massive capital inflows accruing from discovery of natural resources. This was based on the experience of the Netherlands in the 1960's and this led to the development of the literature on Dutch disease in the early 1980s. In other words, it relates to the negative impact on an economy of anything (large oil reserves or remittances) that gives rise to a sharp inflow of foreign currency, leading to currency appreciation, thereby making the country's other products less price competitive on the export market. This, in turn, could lead to a decline in the production of manufactured and other tradable goods. Hence, there is a concern about whether remittances could cause Dutch disease effects.

The link between remittances and sectoral performance is through the exchange rate. This is because it is price of traded goods which could also have effect on the non-traded goods sector through resources re-allocation. There have been several models to explain these links between remittances, sectoral performance and exchange rate. Using conventional models, it was straightforward to show that shocks (be it in the form of inflows of remittances or new discoveries) resulted in an appreciation of the real exchange rate. According to Magud and Sosa (2010), assuming there is a relative price change and a capital-intensive manufacturing tradable sector-as opposed to a labor-intensive non-tradable sector-this relative price change triggers factor reallocation-out of manufacturing-and the appreciation of the real exchange rate, decreasing the competiveness of manufacturing tradable goods.

While an increase in foreign exchange inflows (through remittance for instance) is in principle a positive development due to wealth effects, there have been concerns about the potential negative impact on long-run growth. Recently, a new literature focusing on the relationship between the real exchange rate and growth has surged, in some cases proposing new channels (Magud and Sosa, 2010). For instance, motivated by the successful experiences of China and other eastAsian countries, the view that maintaining an undervalued or "competitive" real exchange rate may foster economic growth has been attracting adherents, which is an export-led growth strategy emerged, as a response to the failure of the import substitution growth strategy that started around the 1950s (Magud and Sosa, 2010). 
More recently, other channels have emerged. For instance, Dooley et al. (2004), argue that an overvalued real exchange rate tends to shift demand away from tradable into non-tradable goods, leading to increase in the real interest rate to maintain internal equilibrium, increasing domestic saving rates. Also, Levy-Yeyati and Sturzenegger (2007) proposed alternative channel: an undervalued real exchange rate is associated with lower real wages, leading firms to higher investment, and to higher saving rates to finance them.

The above suggests that, while real exchange rate overvaluations hurt growth, undervaluations foster it. This is in contrast with another position, linked to the Washington Consensus view, which argues that any real exchange rate misalignment implies a sort of disequilibrium that could affect the growth process (Magud and Sosa, 2010). This view could be summarised as follows: any changes that lead to disequilibrium in the foreign exchange market will generate welfare loss. That is both over valuation and devaluation of exchange rate is injurious to the economic growth. This is against the exportled growth hypothesis that only overvaluation decreases growth, but undervaluation increases it.

Several empirical studies have studied Dutch disease. Gylfason et al (1997) focus on the relationship between Dutch disease and volatility of the real exchange rate, which further lowers productivity and investment in the tradable goods sector. Using cross-sectional and panel regressions based on data for 125 countries over the period 1960-1992. The study found significant inverse relationship between the size of primary sector and economic growth, but not between the volatility of the real exchange rate and growth. In addition, Amuedo-Dorantes and Pozo (2004) assess the impact of workers' remittances on the real exchange rate using a panel of 13 Latin American and Caribbean countries. The basic finding is that an increase in remittances leads to a real exchange rate appreciation. However, doubling remittances appreciates the real exchange rate by $23 \%$. This shows that increased remittance has a decreasing effect on exchange rate appreciation. Also, Arellano et al (2005) studied the dynamics of foreign aid-induced Dutch disease in 73 open economies. The paper presents the relationship between foreign aid and the production of goods for export. Cross-country regressions for 73 aiddependent countries indicate that manufactured good exports, as predicted by the theoretical model, are negatively related to the level of aid. The results are significant after controlling other variables such as initial endowments, transaction costs and the level of development.

Further, Lama and Medina (2010) analyze the welfare effects of stabilizing the exchange rate by appreciation. Using a stochastic dynamic general equilibrium model with learning by doing and nominal rigidities, they show that although exchange rate stabilization sustains tradable goods production, it contributes to misallocate resources and it increases the economy's volatility. Thus, welfare decreases in the case of exchange rate intervention. Meanwhile, Rabbi (2011) using Johansen cointegration and Vector Error Correction models, found that the flow of remittances leads to appreciation of the real exchange rate and decreases the external trade competitiveness of Bangladesh.

Moreover, Owusu-Sekyere et al. (2013) investigates the effect of remittance inflows on real exchange rates in sub-Saharan Africa (SSA) using annual data from 1980 to 2008 for 34 countries. The method of moments estimator developed by Arellano and Bover (1995) and the feasible generalized least squares estimator was utilized. The basic finding, controlling for cross-sectional dependence and individual effects, is that remittances to sub-Saharan Africa as a whole increase the underlying real exchange rates of recipient countries. Hence, the study concludes that the real exchange rate appreciation does not lead to the loss of export competitiveness or a worsening of the trade deficit in the countries in the panel.

Nnikas and Blouchoutzi (2014) test the applicability of the "Dutch Disease" for two small transition economies under a freefloating exchange rate regime namely, Albania and Moldova between 1992 and 2010. The results, based on the ordinary least squares fixed effects, show that the impact of the workers' remittances on the real exchange rate varies among the countries examined.

The existing research on Dutch disease has not only been characterised with mixed results but has also predominantly focused on using the real exchange rate to connect tradable and non-tradable sector performance without considering that remittances come from several countries and countries also trade with different countries. This study uses real effective exchange rate which is a measure of exchange rate across the baskets of commodities being traded.

\section{Analytical Framework and Methodology}

\section{Analytical Framework}


In this section, a simple framework for the analysis of the relationship between remittance, exchange rate and output was developed. It is a variant of the model adopted by Folawewo and Olakojo (2012), as described by Dornbusch (1982) and Sodersten and Reed (1994). The framework assumes two things: stable money demand function and that the Purchasing Power Parity (PPP) holds in the long run. The reason is that monetary policy has an influence on exchange rate through the monetary policy instruments. Hence, monetary policy can serve as a moderating variable between remittances and exchange rates. It is also assumed that the money supply is exogenous and that the money market is at equilibrium such that:

$$
\frac{M}{P}=f(y, r), \text { with } \frac{\partial f}{\partial y}>0, \frac{\partial f}{\partial r}<0
$$

where $M$ is nominal money stock, $P$ is the relative price of non-tradable to tradable, $y$ is real relative output of tradable to non-tradable (given that inverse relationship already exist between y and relative price of non-tradable to tradable) and $r$ is domestic real interest rate, given that only one interest rate rules in an economy.

The demand for real money balance is assumed to depend on domestic interest rate and real income and in equilibrium equals the real money supply. If we express equation (1) in logarithm form this yields

$-\lambda r+\theta y=M-P$

It should be noted that the nominal quantity of money and the real money income are taken as given. Rearranging equation (2) gives

$$
P=M+\lambda r-\theta y
$$

The simple form of PPP assumption is that the exchange rate, $e$, adjust to the ratio of the domestic price level, $p$, and foreign price level $p$. Also, interaction of remittance with relative prices increases the price of domestic non-tradable relative to tradable. Hence,

$$
e=\frac{1}{\text { rem }} \frac{p}{p *}=\frac{1}{\text { rem }} \frac{p n t / p t}{p n t^{*} / p t^{*}}
$$

where $e$ is the price in domestic currency of one unit of foreign currency. The price levels are assumed to be defined over the same basket of goods (tradable and non-tradable), and the PPP theory may be justified by assuming that arbitrage would equalize the price of goods across countries.

Taking the logarithm of equation (4) gives:

$$
e=-r e m+p-p^{*}
$$

where $p, e, p^{*}$ and rem are logged transformation of domestic relative price level, exchange rate, foreign relative price level and remittances. A combination of equations (2) and (5) and some re-arrangement results in a relationship of interest as given by:

$$
y=-\alpha r e m+\alpha M+\lambda \alpha r-\alpha e-\alpha p^{*}
$$

Where $\alpha=1 / \theta$

Equation (6) implies that increase in remittances reduces the output performance of tradable relative to non-tradable sector increase, monetary intervention increases survival of tradable and non-tradable sector, increase in return on investment increases performance of tradable and non-tradable sector and exchange rate appreciation generates reduction in performance of tradable relative to non-tradable. Finally, increase in foreign relative price of non-tradable to tradable reduces the performance of home tradable. This implies appreciation of exchange rate as given equation (4) and less competitiveness of home tradable.

\section{Methodology.}




\section{Empirical Model}

The empirical model, based on equation (6) is specified as follows;

$$
y_{j t}=\beta_{0}+\beta_{1} \text { rem }_{j t}+\beta_{2} M_{j t}+\beta_{3} r_{j t}+\beta_{4} e_{j t}+\varepsilon_{j t}
$$

$\mathrm{y}$, rem, $\mathrm{M}, \mathrm{r}$, and $\mathrm{e}$ are as defined previously (except $\mathrm{e}$ is REER) and ${ }_{\varepsilon}$ is the residual term. jequals any of the two sectors of interest (tradable and non-tradable) and $t$ is the time (1975-2013). It is important to note that the foreign prices are excluded because it is already included in REER computation and also because it is not a policy variable endogenous to both selected countries.

\section{Estimation Procedures and Technique.}

The study first tests for stationarity of variables given the relatively long time series, after which multicollinearity test was performed. These are necessary to guide against misspecification of the estimated models. The study's models were estimated using dynamic ordinary least squares technique (DOLS).

\section{2. 5 Dynamic OLS}

Our econometric methodology in this paper follows the common established practice in time series econometrics as outlined above. Thus, we first test for the properties of the variables using unit root tests. We make use of 3 unit root tests: the Augmented Dickey-Fuller test (ADF), the Phillips-Perron test (PP) and the Kwiatkowski et al. test (KPSS). Following the unit root tests, we conduct cointegration tests to examine if a stable long-run relationship exists amongst the variables of interest. We make use of the Johansen cointegration (1988) test which involves estimation in a vector error correction modelling framework. The Johansen cointegration test involves using the trace and maximum eigenvalue statistics to identify the number of cointegrating vectors of the model.

After the cointegration tests, we make use of the Dynamic Ordinary Least Square (DOLS) of Stock and Watson (1993) to determine the long-run effect/coefficients of remittances and other variables on economic development. The DOLS is used because it is capable of dealing with the potential endogeneity problem of explanatory variables. Specifically, studying the nature of the variables, there is possibility of reverse-causality running between the exchange rate and remittance, foreign direct investment. This situation therefore can raise the possibility of endogeneity as alluded to by Loayza et al. (2007).

Cointegration methods are widely used in empirical macroeconomics and empirical finance. It is well known that in a cointegrationg regression, the ordinary least squares (OLS) estimation of the parameters is super consistent (Vogelsang and Wagner, 2011). When the regressors are endogenous, the limiting distribution of the OLS estimator is contaminated by so-called second order bias term (Phillips and Hansen, 1990). The presence of these bias terms renders inference difficult. Consequently, several modifications to OLS have been proposed which lead to zero mean Gaussian mixture limiting distribution. This in turn makes standard asymptotic inference feasible. These methods are however found in the Fully Modified OLS (FM-OLS) and Dynamic OLS (DOLS).

The DOLS is an alternative approach which has certain advantages over both the OLS and the maximum likelihood procedure. The method was proposed by Stock and Watson (1993). It improves on OLS by coping with small sample and dynamic sources of bias (Al-Azzam and Hawdon, 1999). The Johansen method, being a full information techniques is exposed to problem that parameter estimates in one equation are affected by any misspecification other equations. The Stock and Watson method is by any contrast a robust single equation approach which correct for regressors and for serially correlated errors by a GLS procedure.

In addition, it has the same asymptotic optimality properties as the Johansen distribution. Stock and Watson suggests a parametric approach for estimating long run equilibria in systems which may involve variables integrated of different orders but still cointegrated. The potential of simultaneity bias, small sample bias and endogeneity among the regressors is dealt with by the inclusion of lagged and lead value of first differences of the regressors (Masih and Masih, 1996). In this design, the dynamic OLS estimator performed well relative to other asymptotically efficient estimators (Stock and Watson, 1993).

\section{2. 3. Cointegration Test}


Once variable has been classified as integrated of order I(0), I(1), I(2) etc., it is possible to set up model that lead to stationary relation among the variables where standard inference is possible. The necessary criteria for stationarity among nonstationary variable is called cointegration. Testing for cointegration is a necessary step to check if a model has empirically meaningful relationships. If variables have different trends processes, they cannot stay in fixed long run relationship to each other. This implies that there is no valid base for inference based on standard distributions. If no cointegration can be found, it is necessary to work with variables in differences instead.

The tests of cointegration include the Durbin-Watson statistic test, Engle and Granger's two step procedure, Johansen test of cointegration, etc. DW test statistics as a test of cointegration is carried out by calculating the DW test statistics for the first order autocorrelation under the null hypothesis that the series is a random walk and the parameters are equal to zero, so there is no cointegration. The errors term becomes a random walk with theoretical first order autocorrelation equal unity. Under the null of no cointegration, the DW value will not be significantly different from zero. This test however suffer from two major problems. First, it is extremely sensitive to the assumption of the series being a true random walk and the critical values of the test statistics are not consistent as the number of regressors increases over the sample size. The practical use of this test is therefore limited.

Engle and Granger (1997), however formulated one of the foremost test of cointegration. This test has the advantage that it is intuitive and easy to perform. The test proceeds in two steps and the first step start by estimating the so called cointegrating regression where all variables must be of the same order of integration. This equation represents an economically meaningful steady state or equilibrium relationship among the variables. If the variables are cointegrating, they will share a common trend and form a stationary relationship in the long run.

The second step is to test for a unit root in the residual process of the cointegrating regression. ADF can be performed and under the null of no cointegration. However, finding the lag length so that the residual process becomes white noise is extremely important. The empirical t-distribution is not identical to the Dickey-Fuller, though the tests are similar. The reason is that the unit root test is now applied to a derived variable and the estimated residual from a regression. Asymptotically, the test is independent of which variable occurs in the left hand side of the cointegrating regression.

There are three main problems with the two-step procedure. First, since the test involves an ADF test in the second step, all problem of ADF tests are valid here as well. Second, the test is based on the assumption of one cointegrating vector captured by the cointegrating regression. Thus, care must be taken when applying the test to model with more than two variables. Third, the test assumes a common factor in dynamics of the system.

The superior test for cointegration is the Johansen's test. This is a test which has all desirable statistical properties. The weakness of the test is that it relies on asymptotic properties and is therefore sensitive to specification errors in limited samples. In the end, some judgment in combination with economic and statistical model building is unavoidable. The empirical VAR is formulated with lags and dummy variables so that the residuals become a white noise process. The demand for well specified model is higher than the ARIMA model.

Typically, the system must be integrated of order one and if there are signs of I(2) variables, it must be transformed to I(1) before setting up the VAR. The number of cointegrating vectors, are identical to the number of stationary relationship in the matrix. There are two main tests in the Johansen' test, namely the max Eigenvalue test and trace test. The null hypothesis is that there exists $r$ cointegrating vector against the alternative of $r+1$ vector. Once the basic tests have been performed, conclusion can now be made on the number of cointegrating equation based on the two main tests. Conclusively, the trace test is considered to be superior to the max eigenvalue because of its robustness to skewness and excess kurtosis (Sjo, 2008).

\section{Empirical Analysis}

\section{1 Descriptive Statistics}

The descriptive statistics presented in Table 1 reveals basic characteristics of variables used. For instance, the average remittance as a percentage of GDP was $3.5 \%$ in Nigeria. This implies that remittances account for considerable proportion of gross output in Nigeria. The table shows that sectoral performance also varied across the country. The return on investment is very low which in Nigeria with its average value recording $-1.43 \%$. 
In addition, the coefficient of variation (CV) shows the extent tiltedness of the variables as also indicated by skewness and kurtoses. The tiltedness of remittances in Nigeria is high, indicating that increasing remittance is a recent phenomenon in Nigeria. Hence, the remittance is tilted towards last decade.

Table 1. Descriptive Statistics

\begin{tabular}{lllllllll}
\hline stats & remgdp & Reer & Merexpgdp & Agrigdp & mangdp & Sergdp & m2gdp & Rir \\
mean & 3.45 & 156.03 & 37.83 & 27.04 & 3.41 & 22.42 & 24.54 & -1.43 \\
Sd & 3.86 & 131.21 & 9.05 & 5.72 & 0.49 & 3.98 & 6.85 & 17.14 \\
skewness & 1.12 & 1.58 & 0.28 & 0.24 & 0.44 & 0.44 & 0.69 & -0.76 \\
kurtosis & 3.24 & 4.46 & 3.12 & 3.04 & 2.02 & 2.80 & 3.17 & 3.46 \\
Cv & 1.12 & 0.84 & 0.24 & 0.21 & 0.14 & 0.18 & 0.28 & -12.00 \\
\hline
\end{tabular}

\section{Source: Computed}

\section{2. Multicollinearity Test}

The multicollinearity test is presented in Table 2. The Table shows the strength of relationship between any pair of variable used in the study. In this case only the exogenous variables were considered. The result shows that the extent of high positive correlation between any pair of explanatory variable is weak. Although the expected sign is noticed between remittances and REER, but the relationship is not significant indicating unlikeliness of remittances to generate appreciation of exchange rate. The implication of this test is that the explanatory variables as identified can be together included as exogenous variables in a single model without running into serious multicollinearity problem.

Table 2. Correlation among explanatory variables

\begin{tabular}{|l|l|l|l|l|}
\hline & \multicolumn{4}{l}{ Nigeria } \\
\hline & REMGDP & REER & M2GDP & RIR \\
\hline REMGDP & 1.0 & -0.3 & 0.0 & 0.2 \\
\hline REER & -0.3 & 1.0 & 0.3 & 0.1 \\
\hline M2GDP & 0.0 & 0.3 & 1.0 & 0.2 \\
\hline RIR & 0.2 & 0.1 & 0.2 & 1.0 \\
\hline
\end{tabular}

Source: Computed

\section{3. Unit Root Test}

The essence of the unit root test is not only because the data is characterized with fairly long time series, creating potential for non-stationarity of the time series data across the cross-sectional observations, but also because having knowledge of the order of integration of guides against miss-specification of the estimated models. The variables to be used across models to be estimated are tested for the unit roots. Given the results in Table 3, it could be concluded that all variables, except real interest rate.

Table 3. Unit root tests

\begin{tabular}{|l|l|l|l|l|l|l|l|l|l|}
\hline \multicolumn{2}{|l|}{ Intermediate ADF test results at Level } & \multicolumn{2}{l|}{ Intermediate ADF test results at First Difference } \\
\hline Series & Prob. & Lag & Max Lag & Max Lag & Series & Prob. & Lag & Max Lag & Obs \\
\hline REMGDP & 0.3204 & 0 & 7 & 6 & D(REMGDP) & 0.0000 & 0 & 6 & 30 \\
\hline REER & 0.3482 & 0 & 7 & 7 & D(REER) & 0.0073 & 0 & 7 & 31 \\
\hline MEREXPGDP & 0.0641 & 0 & 9 & 9 & D(MEREXPGDP) & 0.0000 & 1 & 9 & 36 \\
\hline
\end{tabular}




\begin{tabular}{|l|l|l|l|l|l|l|l|l|l|}
\hline AGRIGDP & 0.2669 & 0 & 7 & 7 & D(AGRIGDP) & 0.0000 & 1 & 7 & 30 \\
\hline MANGDP & 0.3710 & 0 & 7 & 7 & D(MANGDP) & 0.0002 & 0 & 7 & 31 \\
\hline SERGDP & 0.9570 & 0 & 7 & 7 & D(SERGDP) & 0.0012 & 0 & 7 & 31 \\
\hline M2GDP & 0.0521 & 0 & 9 & 9 & D(M2GDP) & 0.0000 & 0 & 9 & 37 \\
\hline RIR & 0.0000 & 0 & 9 & 9 & D(RIR) & 0.0000 & 1 & 9 & 36 \\
\hline
\end{tabular}

Source: Computed

\section{4 Impact of Remittance and Exchange rate on Tradable and Non-tradable sector in Nigeria}

\section{4. 1 Agricultural Sector (Tradable sector)}

The results presented in Table 4 revealed that Nigeria agricultural sector, measured as agricultural output as share of GDP, which is a tradable sector is negatively influenced by increase in remittance inflow and the depreciation of the real effective exchange rate. Such that an increase in remittance inflow, measured as remittance as share of GPS, by $1 \%$ leads to reduction in the agricultural sector output by $0.8 \%$. While the depreciation of real effective exchange rate by 1 basis point reduces the share of agricultural output in Nigeria GDP by $0.04 \%$. The effect of remittance on agricultural output is expected. In Nigeria, remittance serves as additional source of income to those engaging in agricultural activities, which comes with little or no stress. As a result the flow of extra income to those engaging in agricultural activities through remittance might serve as disincentive to them to intensive their effort while working on their farm. Thereby reducing the sector output as a share of GDP. In addition, depreciation of exchange rate is observed to reduce the share of agricultural sector output to Nigeria GDP, this might be as a result of uncompetitive nature of the Nigeria agricultural product in the world commodity market.

Furthermore, increase in money stock as share of GDP and real interest rate contribute positively to Nigeria agricultural sector. The observed effect is because the agricultural sector is less capital intensive like other sector such as manufacturing, thus, increase in interest rate stimulating agricultural sector performance.

\section{4. 2 Manufacturing Sector (Tradable Sector)}

Another tradable sector considered in the study is the manufacturing sector, the result obtained as presented in Table 4, shows that remittance as well as appreciation of the real effective exchange rate has negative and significant effect on the Nigerian manufacturing sector performance. Furthermore, the study shows that expansionary monetary policy in the form of increase in money stock (measured as broad money as share of GDP) and reduction in real interest rate enhance manufacturing sector performance. Manufacturing sector is a capital intensive sector, an increase in real interest rate increases firm's cost of borrowing, which in turn increases their cost of operation, thereby impacting negatively on their performance.

\section{Table 4. DOLS Estimations}

\begin{tabular}{|c|c|c|c|c|c|c|c|c|}
\hline & \multicolumn{2}{|c|}{ Agriculture } & \multicolumn{2}{|c|}{ Manufacture } & \multicolumn{2}{|l|}{ Services } & \multicolumn{2}{|c|}{ Merchandise export } \\
\hline & Coef. & t-stat & Coef. & t-stat & Coef. & t-stat & Coef. & t-stat \\
\hline Constant & 35.261 & $9.172^{\star \star \star}$ & -3.005 & -1.342 & -30.186 & -1.927 & 122.835 & $10.671^{* * *}$ \\
\hline remgdp & -0.778 & $-2.416^{*}$ & -0.830 & $-4.442^{\star \star \star}$ & -2.215 & -1.688 & 3.727 & 3. $865^{\star *}$ \\
\hline reer & -0.044 & $-6.184^{\star \star \star}$ & 0.016 & $4.125^{* * *}$ & 0.091 & $3.136^{* *}$ & -0.071 & $-3.335^{\star \star}$ \\
\hline m2gdp & 0.641 & $9.129^{\star \star \star}$ & 0.149 & 1. $979^{*}$ & 0.670 & 2. $340^{*}$ & -1.746 & $-8.304^{\star * \star}$ \\
\hline Rir & 1.193 & $7.962^{\star \star \star}$ & -0.171 & $-2.725^{\star \star}$ & -1.056 & -1.728 & 0.700 & 1.559 \\
\hline Statistics & & & & & & & & \\
\hline
\end{tabular}




\begin{tabular}{|l|l|l|l|l|l|l|l|l|}
\hline$R^{2}$ & 0.950 & & 0.723 & & 0.708 & & 0.732 & \\
\hline
\end{tabular}

\section{4. 3 Services Sector}

Service sector is a non-tradable sector, the effect of remittance on this sector is negative, although insignificant at $10 \%$ significant level. This suggest that the impact of additional income through remittance has less influence on the performance of the service sector compared to agricultural sector and the manufacturing sector in Nigeria. Also, the study findings revealed that depreciation of real effective exchange rate leads to improvement in service sector performance. In addition, the study revealed that an increase in money stock contributes significantly to service sector performance. This might be as a result of availability of money in circulation, which serves as medium of exchange. Hence, as more currency is in circulation, it facilitates business transaction, thereby increasing the demand for service sector activities, and as such stimulating the sector performance. On the contrary, increase in real interest rate lowers service sector output as it increase the cost of operation. Thereby lowering the sector scale of operation, indirectly reducing the sector overall output.

\section{4. 4 Merchandise Exports}

The last sector to be considered is the merchandise export, which entails Nigeria export performance. The study results point out that remittance aid merchandise export. An increase in remittance by $1 \%$ contributes to increase in merchandise export by 3. $7 \%$. Depreciation of the real exchange rate and money stock were observed to contribute to reduction in merchandise export and the effect is statistically significant at $5 \%$. However, real interest rate had a positive effect on merchandise export, the observed effect is statistically insignificant.

\section{Conclusion}

This study investigates the linear relationship between remittances and real effective exchange rate on one hand and the impact of remittances and exchange rate on tradable and non-tradable sector in Nigeria. Employing DOLS regression technique on annual data ranging from 1981 and 2013, the basic result is that remittances influence performance of tradable agriculture, manufacturing sector and merchandise export sector in line with Dutch disease idea. Also, we found evidence that changes in exchange rate act as a channel of impact of Dutch disease on all sectors. Therefore, it can be deduced that real exchange rate appreciation leads to the loss of merchandise export competitiveness in Nigeria. Hence, since remittances influence agriculture and manufacturing sectors in an undesired manner in Nigeria, there should be conscious effort at encouraging agriculture and manufacturing investment remittance spending rather than spending those remittances on consumption.

\section{References}

[1] Abiodun O. Folawewo and Solomon A. Olakojo (2012). Inflation and Exchange Rate in Nigeria: Evidence from Recent Data. Financial Sector Issues and Economic Development in Nigeria. Volume 2 of Essays in Honour of Professor Adedoyin Soyibo. Ibadan University Press. Edited by Olaniyan O., Lawanson A. O., and Alayende B. ; Page 69-85.

[2] Amuedo-Dorantes, C., Pozo, S. (2004), "Workers' Remittances and the Real Exchange Rate: a Paradox of Gifts, " World Development 32, 1407-1417.

[3] Arellano, C., A. Bulir, T. Lane, L. Lipschitz. 2005. "The Dynamic Implications of Foreign Aid and Its Variability, " IMF Working Paper 05/119, Washington: International Monetary Fund.

[4] Dooley, M., D. Folkerts-Landau and P. Garber (2003), "An Essay on the Revived Bretton Woods System, "NBER Working Paper No. 9971.

[5] Dornbusch, R. 1982. Equilibrium and Disequilibrium Exchange Rates. Working Papers Institute of Technology (MIT).

309, Massachusetts

[6] Fajnzylber, P., López, H., 2008. Remittances and Development: Lessons from Latin America. WorldBank, Washington, DC.

[7] Gylfason, T., T. T. Herbertson, and G. Zoega (1997), "A Mixed Blessing: Natural Resources and Economic Growth, " Macroeconomic Dynamics, Vol. 3, 204-25. 
[8] Lama, R. and J. P. Medina (2010), "Is Exchange Rate Stabilization an Appropriate Cure for the Dutch Disease?, " IMF Working Paper.

[9] Levy Yeyati, E., and F. Sturzenegger. 2007. "Fear of Appreciation, "World Bank Policy Research Working Paper 4387.

[10] Magud, Nicolás and Sosa, S. 2010. When and Why Worry About Real Exchange Rate Appreciation? The Missing Link between Dutch Disease and Growth, IMF Working Paper, WP/10/271.

[11] Nnikas, C. and Blouchoutzi, A. 2014. Emigrants' Remittances and the "Dutch Disease" in Small Transition Economies: The Case of Albania and Moldova. Revista Română de Statistică nr. 1 / 2014: 45-65.

[12] Owusu-Sekyere, E., Eyden, R., and Kemegue, F. M. 2013. Remittances and the Dutch Disease in SubSaharan Africa: A Dynamic Panel Approach. Contemporary $\quad$ Economics, 8(3): 289-298.

[13] Rabbi, F. 2011. Remittances and the Dutch Disease: Macroeconomic Consequences in Bangladesh. A thesis submitted in fulfilment of the requirements of the degree of Master in Commerce (Honours), University of Western Sydney.

[14] Sodersten, Bo and Geoffrey Reed. 1994. International Economics. Basingstoke: Macmillan. 